\title{
RECENZJA MONOGRAFII MARIUSZA
}

\section{ANTONIEGO KAMIŃSKIEGO, OBRONA}

\section{NARODOWA REPUBLIKI ESTONII, TORUŃ 2019²}

Problematyka polityki bezpieczeństwa Estonii pozostaje bardzo słabo zbadana i opisana w literaturze krajowej. Istniejące publikacje w bardzo ograniczonym stopniu odnoszą się do tej tematyki, przedstawiając ją zazwyczaj w szerszym kontekście polityki państw bałtyckich ${ }^{3}$. Mariusz A. Kamiński częściowo wypełnia tę lukę badawczą.

Recenzowana książka została napisana na podstawie bardzo solidnej bazy źródłowej. Wykorzystano 46 aktów prawnych, 124 pozycje naukowe, 13 strategicznych dokumentów planowania obronnego oraz liczne źródła netograficzne. Autor sięgnął nie tylko po opracowania ekspertów doktryny nauki o bezpieczeństwie, lecz także po publikacje twórców koncepcji polityki zagranicznej i bezpieczeństwa Estonii (m.in. prace byłego prezydenta Lennarta Meri oraz byłego i obecnego ministra obrony Jürija Luika). Na szczególne wyróżnienie zasługuje wykorzystanie źródeł estońskich ${ }^{4}$, zazwyczaj marginalizowanych lub wręcz pomijanych w polskich opracowaniach ${ }^{5}$. Dla pełniejszego zrozumienia koncepcji obrony narodowej Republiki Estonii warto było rozważyć poszerzenie bazy bibliograficznej o kilka pozycji dotyczących procesu rozszerzenia NATO o państwa bałtyckie ${ }^{6}$. Nie stanowi to jednak zarzutu wobec książki, której ostrze wywodu kieruje się wobec systemu obrony narodowej i traktuje kwestie zewnętrznej polityki bezpieczeństwa jako wątek drugorzędny.

Zakres chronologiczny publikacji obejmuje - zgodnie z zapowiedziami autora we wstępie - okres od momentu odzyskania niepodległości w 1991 do 2018 r. Zadeklarowana cezura czasowa nie jest jednak (i słusznie!) przeszkodą dla sięgnięcia poza ten okres, w tym

\footnotetext{
${ }^{1}$ Ambassador - Embassy of the Republic of Poland in Tallinn.

${ }^{2}$ M.A. Kamiński, Obrona Narodowa Republiki Estonii, Toruń: Wydawnictwo Adam Marszałek 2019, ss. 273.

${ }^{3}$ Np. J. Kozakiewicz, Polityka bezpieczeństwa państw baltyckich, Kraków 2003, s. 264.

${ }^{4}$ M.in. A. Laaneots, Eesti riigikaitse sünd. 1991-2017, Riigikogu Toimetised 2017, t. 36.

${ }_{5}$ Przykładami monografii pozbawionych odniesień do źródeł estońskich są m.in.: S. Sagan (red.), Ustrój państwowy Republiki Estonii, Wyd. Uniwersytetu Rzeszowskiego, 2018, s. 118 oraz J. Kozakiewicz, op. cit.

${ }^{6}$ Np. często cytowana w tym kontekście pozycja: R. Asmus, R. C. Nurick, NATO Enlargement and the Baltic States, Survival, vol. 38 no 2, Summer 1996, p. 121-142.
} 
także do historii międzywojnia oraz początków procesu transformacji ustrojowej, sięgającej końca lat 80. XX wieku.

Na konstrukcję książki składa się wstęp, osiem rozdziałów, zakończenie, bibliografia, wykaz rysunków i tabel oraz wykaz skrótów. Atutem książki jest solidne ugruntowanie metodologiczne oraz dokonywanie podsumowań w każdym z rozdziałów, co czyni wywód klarownym.

W rozdziale pierwszym autor dokonuje wprowadzenia metodologicznego oraz przedstawia dwie hipotezy główne i cztery szczegółowe. Wydają się wskazane właściwie, choć główną hipotezę roboczą (brzmiącą „W rezultacie doświadczeń z pierwszych lat po ogłoszeniu niepodległości w 1991 r. - zwłaszcza bliskiej współpracy z neutralną Finlandią a następnie integracji z NATO i UE oraz permanentnego poczucia zagrożenia ze strony Federacji Rosyjskiej, Estonia zbudowała system obrony narodowej dostosowany do jej potrzeb obronnych jako małego państwa o trudnym położeniu geopolitycznym”) rozszerzyłbym initio o doświadczenia międzywojenne. Miały one istotny wpływ na odrzucenie w latach 90. XX w. modelu neutralnego państwa - na wzór Finlandii.

W rozdziale drugim stosunkowo dobrze są opisane uwarunkowania historyczne, choć nie odnoszą się one do manewrowości polityki Estonii w latach 1918-1940. Poszukiwała ona wówczas możliwie optymalnego układu politycznego, gwarantującego niezależność terytorialną i niepodległość państwa. Słabość Ligi Narodów (brak członkostwa Niemiec i Związku Sowieckiego, izolacjonistyczna polityka Stanów Zjednoczonych) oraz niemożność skutecznego zawiązania sojuszy wojskowych z Polską, Łotwą i Finlandią pchnęły Estonię ku wyborowi w 1938 r. statusu państwa neutralnego, który okazał się błędem. Doświadczenia historyczne w tym względzie miały dla Estonii ważne znaczenie w kontekście wyboru wektora polityki zagranicznej w latach 90. XX w. Autor uchyla się także w tej części publikacji od bardziej precyzyjnego komentarza dotyczącego mniejszości rosyjskojęzycznej. Stanowi ona ok. $25 \%$ populacji i ma charakter niejednorodny ${ }^{7}$. W jej skład wchodzi: 157 tys. obywateli estońskich, 90 tys. obywateli rosyjskich oraz 83 tys. apatrydów (tzw. non-citizens) ${ }^{8}$. Ocenia się, że większość społeczności rosyjskojęzycznej „wiąże swoją przyszłość z Estonią i postrzega siebie jako obywateli Unii Europejskiej”,", co ma różnorakie znaczenie dla bezpieczeństwa państwa. Jako jeden z przykładów można wymienić brak poparcia

\footnotetext{
${ }^{7}$ Population by Ethnic Nationality, Statistics Estonia, January 1 2017, https://www.stat.ee/34278, (10.07.2018).

$8 \mathrm{~W}$ tym przypadku tzw. osoby z nieokreślonym obywatelstwem (undetermined citizenship) lub tzw. szarym paszportem - osoby, które nie ubiegały się o obywatelstwo Estonii i które nie posiadają innego obywatelstwa. Taki stan prawny wynikał z decyzji Federacji Rosyjskiej (Akt Obywatelski z 1992) o nieprzyznaniu obywatelstwa FR byłym obywatelom ZSRS pozostałym w b. republikach sowieckich. Takie osoby posiadają m.in. dokumenty podróży, prawo do równego traktowania oraz prawo do czynnego udziału w wyborach lokalnych. Zob.: G. Mihaita, M. Sebe, Estonia's Non-Citizens, Citizens of the European Union?, January, 2016 [w:] https://citizenrights.euroalter.com/wpcontent/uploads/2016/01/Mihaita-and-Sebe-Estonia\%E2\%80\%99s-Non-Citizens-Citizens-of-the-European-Union2015.pdf, (27.06.2019); J. Croft, Non-Citizens in Estonia and Latvia: Time for Change in Changing Times?, OSCE Yearbook 2015, Baden-Baden 2016, s. 181-195.

9 P. Goble, Experts: Estonia has successfully integrated nearly 90\% of its ethnic Russians, March 1, 2018 http://estonianworld.com/security/experts-estonia-successfully-integrated-nearly-90-ethnic-russians/, (10.07.2018).
} 
w społeczeństwie dla partii o prokremlowskim i antyeuropejskim ostrzu (ten elektorat jest reprezentowany przez Estońską Zjednoczoną Partię Lewicy, na którą średnio oddaje głos ok. 0,1\%). Mniejszość rosyjskojęzyczna oddaje w większości głos na proeuropejską Partię Centrum (ocenia się, że jest to ok. $70 \%{ }^{10}$ ).

Najwięcej zastrzeżeń można skierować pod adresem rozdziału trzeciego. Podejmuje on tematykę zewnętrznych i wewnętrznych czynników wpływających na koncepcję obrony narodowej Estonii w latach 1991-2018. O ile autor właściwie przedstawia etapy rozwoju niepodległego państwa (szczególnie w okresie do momentu przystąpienia do Sojuszu Północnoatlantyckiego w $2004^{11}$ ), dokonuje słusznej identyfikacji dylematów wyboru strategicznego kierunku polityki bezpieczeństwa odrodzonego państwa ${ }^{12}$ i poprawnie opisuje budowę prawnych i faktycznych zdolności obronnych państwa, o tyle niedostatecznie uporządkowuje zewnętrzny wymiar polityki bezpieczeństwa. Po pierwsze, Estonia opiera swoje bezpieczeństwo (jako państwo małe, o czym autor wspomina w drugim rozdziale, nie odnosząc się jednak do literatury $\mathrm{w}$ tym zakresie) przede wszystkim na członkostwie w Sojuszu Północnoatlantyckim i innych organizacjach międzynarodowych o profilu bezpieczeństwa (Organizacja Narodów Zjednoczonych ${ }^{13}$, Unia Europejska ${ }^{14}$, Organizacja Bezpieczeństwa i Współpracy w Europie oraz Rada Europy). Podkreślenia ponadto wymaga, że pozycja Estonii w NATO ewoluowała; między 2004 a 2014 r. miała charakter polityczny, tj. zgodnie z Aktem Założycielskim między NATO a Federacją Rosyjską o Wzajemnych Stosunkach, Współpracy i Bezpieczeństwie nie przewidywano na jej terytorium (podobnie jak innych państw) dyslokacji sojuszniczych sił zbrojnych, jednakże aneksja Krymu przez Rosję zmieniła sytuację geopolityczną i politykę Sojuszu, której efektem było rozmieszczenie tzw. wysuniętej obecności wojskowej NATO (eFP-enhanced Forward Presence) na terytoriach państw bałtyckich i w Polsce ${ }^{15}$. Zmieniło to charakter członkostwa z politycznego na politycznowojskowy ${ }^{16}$. Po drugie, Estonia stara się skutecznie dywersyfikować politykę bezpieczeństwa

10 J. Kriwonosowa, Estonia's 'Russian Question', Intersection, September 2017 http://intersectionproject.eu/ article/russia-europe/estonias-russian-question, (10.10.2019).

${ }^{11}$ Przedstawione m.in. w pracach estońskiego historyka Hellara Lilla (np. Eesti riigikaitsepoliitika ujunemisest. Esimesed visioonid 1991-1995, Akadeemia 9 (2009), s. 1740-1751.

${ }^{12}$ Choć trzeba podkreślić, że możliwość nawiązania bliskich relacji z Rosją (wskazana, obok integracji z Zachodem oraz wyboru modelu neutralnego państwa, jako jeden z kierunków rozwoju politycznego Estonii) należy zaliczyć wyłącznie do kategorii teoretycznych; nie miała ona żadnego oparcia wśród miejscowych elit.

${ }^{13}$ Estonia obejmie - po raz pierwszy w historii - niestałe członkostwo w Radzie Bezpieczeństwa ONZ w latach 2020-2021.

${ }^{14} \mathrm{~W}$ pracy brakuje odniesień do rozwoju współpracy obronnej w UE i zaangażowania Estonii w takie projekty jak Stała Współpraca Strukturalna (PESCO-Permanent Structured Cooperation) czy Europejski Fundusz Obronny (EDF-European Defence Fund) utworzone w 2017.

15 Zob. m.in. pkt 40 Deklaracji końcowej szczytu NATO w Warszawie, wyd. przez Szefów Państw i Rządów uczestniczących w posiedzeniu Rady Północnoatlantyckiej w Warszawie w dniach 8 i 9 lipca 2016 r.: „zdecydowaliśmy się ustanowić naszą wysuniętą obecność w Estonii, na Łotwie, na Litwie i w Polsce, tak aby jednoznacznie zademonstrować całość naszych sił i środków obronnych oraz solidarność, determinację i zdolność państw sojuszniczych do działania poprzez natychmiastowe reagowanie na jakikolwiek objaw agresji (...)"[w:] https://www.bbn.gov.pl/ftp/dok/03/37-40_KBN_Deklaracja_szczytu.pdf, (22.11.2019).

${ }_{16}$ Zob. K. Stoicescu, P. Jarvenpaa, Contemporary Deterrence. Insights and Lessons from Enhanced Forward Presence, ICDS, Tallinn, January 2019, p.1. 
poprzez umiejętne budowanie ścisłych relacji z największymi i najważniejszymi sojusznikami. Priorytetem pozostaje współpraca ze Stanami Zjednoczonymi jako kluczowego gwaranta bezpieczeństwa i obrony państw bałtyckich, ale niekoniecznie odstraszania (brak obecności wojsk amerykańskich w Estonii, na Litwie i Łotwie). W dalszej kolejności rozwijana jest współpraca $\mathrm{z}$ mocarstwami nuklearnymi: Wielką Brytanią (państwo ramowe w eFP w Estonii; Estonia pozostaje członkiem kierowanych przez Wielką Brytanię Wspólnych Sił Ekspedycyjnych) oraz Francją (państwo uczestniczące w eFP w Estonii; Estonia bierze udział we francuskiej operacji wojskowej w Mali, pozostając członkiem powołanej przez Francję Europejskiej Inicjatywy Interwencyjnej). W gronie najbliższych państw sprzymierzonych należy też wskazać na Polskę (autor całkowicie pominął tę kwestię), największego sojusznika w regionie środkowoeuropejskim, o podobnej percepcji zagrożenia, doświadczeniach historycznych i rosnącej roli z uwagi na wzmacnianie współpracy wojskowej ze Stanami Zjednoczonymi. Słabością tego rozdziału jest także brak szerszego ujęcia zagrożeń konwencjonalnych i hybrydowych (w tym w obszarze dezinformacji) ze strony Federacji Rosyjskiej, które de facto i de jure determinują politykę bezpieczeństwa Republiki Estonii.

Największa wartość publikacji została zawarta w kolejnych rozdziałach, w których autor, dzięki przygotowaniu zarówno w obszarze nauk prawnych, jak i nauk o bezpieczeństwie, skutecznie uporządkował wiedzę w obszarze systemu obrony narodowej Estonii. W rozdziale czwartym M.A. Kamiński wnikliwie dokonuje przeglądu strategicznych dokumentów planowania obronnego i ich wpływu na wizję systemu obrony narodowej Estonii. Trafnie wskazuje na ewolucję i wzrost znaczenia niemilitarnych elementów obrony, uwypuklając potencjał państwa estońskiego w zakresie cyberprzestrzeni, którego rozwój stanowi jeden z priorytetów rządu estońskiego. W rozdziale piątym znajdujemy interesujący opis kluczowych elementów aktów prawnych, składających się na prawne instrumentarium systemu obrony narodowej Estonii. Analizie poddano nie tylko dokumenty dotyczące bezpośrednio obrony narodowej oraz stanów nadzwyczajnych i zarządzania kryzysowego, lecz także akty prawne stanowiące ich uzupełnienie (np. ustawa o bezpieczeństwie cybernetycznym).

W kolejnym rozdziale autor szczegółowo przedstawia rolę organów państwa począwszy od Riigikogu, przez prezydenta Republiki, naczelne organy administracji rządowej po organy doradcze i komitety właściwych w sprawach bezpieczeństwa i obrony narodowej. $\mathrm{Na}$ polskim gruncie, w warunkach tworzenia Wojsk Obrony Terytorialnej, ciekawym i przydatnym jest rozdział siódmy traktujący o organizacji obrony militarnej państwa, w tym o estońskiej Lidze Obrony i organizacjach przy niej afiliowanych (jak np. Naiskodukaitse organizacja kobieca Obrończynie Ojczyzny). Mają one bardzo ważne, często niedoceniane znaczenie dla budowania w społeczeństwie świadomości bezpieczeństwa i obrony państwa.

Rozdział ósmy, dotyczący organizacji obrony niemilitarnej państwa, pozostaje istotnym elementem publikacji. Na wyróżnienie zasługuje szczególnie wyczerpująca analiza polityki bezpieczeństwa wewnętrznego państwa. Jednocześnie jednak autor bagatelizuje miejsce dyplomacji w polityce bezpieczeństwa państwa, poświęcając jej zaledwie 1,5 strony, oraz 
marginalizuje rolę funkcjonującego w Tallinnie Centrum Doskonałości NATO ds. Bezpieczeństwa Cybernetycznego (NATO Cooperative Cyber Defence Centre of Excellence), które stanowi skuteczną instytucję pomocną w budowaniu relacji estońskiego resortu obrony z kluczowymi sojusznikami (m.in. USA i Wielka Brytania).

Autor słusznie konkluduje, że cel badawczy, jakim było usystematyzowanie i pogłębienie wiedzy na temat systemu obrony narodowej Estonii, został spełniony. Pomimo kilku uchybień, dotyczących przede wszystkim zewnętrznych wymiarów polityki bezpieczeństwa Estonii, recenzowana książka stanowi ważną lekturę dla historyków i politologów, a także wszystkich zainteresowanych współczesnymi stosunkami międzynarodowymi. Wypełnia częściowo lukę badawczą dotyczącą obronności Estonii, stanowiąc do tej pory najbardziej przekrojową pozycję literatury polskiej dotyczącą tego zagadnienia. Zgodnie z zapowiedzią autora należy wyrazić nadzieję, że będzie on kontynuował swoje prace badawcze nad systemami obrony narodowej innych państw bałtyckich.

\section{BIBLIOGRAFIA}

Asmus Ronald D., Nurick Robert C. 1996. "NATO Enlargement and the Baltic States." Survival 38(2): 121-142.

Croft Jennifer, 2016. Non-Citizens in Estonia and Latvia: Time for Change in Changing Times? Baden-Baden: OSCE Yearbook.

Deklaracja końcowa szczytu NATO w Warszawie wydana przez Szefów Państw i Rządów uczestniczących w posiedzeniu Rady Północnoatlantyckiej w Warszawie w dniach 8 i 9 lipca 2016 r. In https://www.bbn.gov.pl/ftp/dok/03/37-40_KBN_Deklaracja_szczytu.pdf.

Goble Paul. 2019 Experts: Estonia has successfully integrated nearly 90\% of its ethnic Russians, March 1, 2018 In http://estonianworld.com/security/experts-estoniasuccessfully-integrated-nearly-90-ethnic-russians/.

Kozakiewicz Jerzy. 2003. Polityka bezpieczeństwa państw bałtyckich, Kraków Instytut Studiów Strategicznych.

Kriwonosowa J. 2017. Estonia's 'Russian Question', Intersection, September 2017 In http://intersectionproject.eu/article/russia-europe/estonias-russian-question.

Laaneots, Eesti riigikaitse sünd. 1991-2017, Riigikogu Toimetised 2017, t. 36.

Lill H. 2009. "Eesti riigikaitsepoliitika ujunemisest. Esimesed visioonid 1991-1995." Akadeemia 9.

Mihaita G. 2016. Sebe M., Estonia's Non-Citizens, Citizens of the European Union?, January In https://citizenrights.euroalter.com/wp-content/uploads/2016/01/Mihaita-and-SebeEstonia\%E2\%80\%99s-Non-Citizens-Citizens-of-the-European-Union-2015.pdf.

Population by Ethnic Nationality, Statistics Estonia, January 12017 In https://www.stat.ee/34278.

Sagan Stanisław (red.) 2018. Ustrój państwowy Republiki Estonii. Rzeszów: Wyd. Uniwersytetu Rzeszowskiego.

Stoicescu Kaiev, Jarvenpaa Pauli. 2019. Contemporary Deterrence. Insights and Lessons from Enhanced Forward Presence. Tallinn: ICDS. 